\title{
Insect Glycan
}

National Cancer Institute

\section{Source}

National Cancer Institute. Insect Glycan. NCI Thesaurus. Code C158047.

An oligosaccharide protein modification that is synthesized by insect cells. 